\title{
Mechanisms for synchronized burst firing in pyramidal cells using oscillatory inhibition: a model for attentional control
}

\author{
Caroline Fischer ${ }^{*}$, Paul HE Tiesinga, Marije ter Wal \\ From 24th Annual Computational Neuroscience Meeting: CNS*2015 \\ Prague, Czech Republic. 18-23 July 2015
}

Pyramidal cells have two different action potential initiation sites; one at the soma, which receives inputs from synapses contacting the basal dendrites or the soma, and one at the distal apical dendrite and tuft [1]. At the latter, calcium spikes can be elicited resulting in a plateau potential due to the influx of calcium that causes the pyramidal cell to fire bursts of action potentials [2]. This mechanism can be used to enhance the effect of top-down synaptic inputs that are received on the distal apical dendrite and tuft on activating its downstream targets. Calcium spikes can be elicited either by convergence of forward-propagating inputs at the tuft or by simultaneous depolarization from back-propagating action potentials and excitation at the tuft [3], referred to as FAC and BAC, respectively.

We investigated whether these two firing patterns can be synchronized by oscillatory inhibition in order to transmit top-down or combined top-down and bottom-up information to different brain areas. We hypothesize this mechanism as an explanation for the synchronization of burst spiking to distant local field potentials at beta frequencies $(12-20 \mathrm{~Hz})$ that was recorded in the prefrontal cortex and the anterior cingulate cortex during attentional control [4].

We simulated the behavior of pyramidal cells stimulated by oscillatory inhibition at the tuft and noisy excitatory inputs at the basal dendrite and tuft. First, we investigated the occurrence and phase-locking of FAC and $\mathrm{BAC}$ firing in one cell as function of the ratio of excitatory basal and tuft inputs. Second, we examined the synchronization of a population of pyramidal cells downstream to oscillatory inhibition with frequencies in the beta range. The pyramidal cells were modeled using

\footnotetext{
* Correspondence: caroline.fischer@student.ru.nl

Department of Neuroinformatics, Donders Centre for Neuroscience, Radboud University Nijmegen, 6525 AJ, Nijmegen, the Netherlands
}

four compartments and including calcium dynamics in the apical dendrite and tuft [5].

For single pyramidal cells FACs predominantly occur when the tuft receives stronger excitation than the basal dendrites, while BACs occur predominantly when the tuft and basal dendrites are excited equally strong. Both mechanisms have in common that they dominate the behavior of the pyramidal cell only when oscillatory inhibition is in the lower frequency range $(2-20 \mathrm{~Hz})$. For a 1:2 ratio between excitatory basal and tuft input FACs accounted for up to $85 \%$ of all spike events, whereas for a ratio of 1:1 BACs constituted up to $68 \%$. Bursts activated by FACs and BACs were strongly phase-locked to the inhibitory drive, while bursts activated by other mechanisms had a lower coherence. The synchrony between pairs of pyramidal cells was quantified using the Schreiber measure [6] with the smoothing parameter set to $\sigma=5 \mathrm{~ms}$. When stimulated in the beta frequency range the synchrony between pairs of pyramidal cells was on average 0.78 . Taken together, the results show that FAC and BAC firing can be used in conjunction with oscillatory inhibition to produce synchronized burst firing in pyramidal cells. This provides an effective means to transmit top-down or combined top-down and bottom-up information downstream.

\section{Acknowledgements}

This work is supported by funding from the European Union's Seventh

Framework Programme (FP7/2007-2013) under grant agreement no. 600925.

Published: 18 December 2015

\section{References}

1. Yuste R, Gutnick MJ, Saar D, Delaney KR, Tank DW: Ca2+ Accumulations in Dendrites of Neocortical Py-ramidal Neurons: An Apical Band and Evidence for Two Functional Compartments. Neuron 1994, 13:23-43. 
2. Schiller J, Schiller Y, Stuart G, Sakmann B: Calcium action potentials restricted to distal apical dendrites of rat neocortical pyramidal neurons. J Physiol 1997, 505(3):605-616.

3. Larkum ME, Zhu JJ, Sakmann B: A new cellular mechanism for coupling inputs arriving at different cortical layers. Nature 1999, 398:338-341.

4. Womelsdorf T, Ardid S, Everling S, Valiante TA: Burst Firing Synchronizes Prefrontal and Anterior Cingulate Cortex during Attentional Control. Current Biology 2014, 24:2613-2621.

5. Bahl A, Stemmler MB, Herz VM, Roth A: Automated optimization of a reduced layer 5 pyramidal cell model based on experimental data. J Neurosci Methods 2012, 210:22-34.

6. Kreuza T, Haas JS, Morellic A, Abarbanel HDI, Politi A: Measuring spike train synchrony. J Neurosci Methods 2007, 165:151-16.

doi:10.1186/1471-2202-16-S1-P259

Cite this article as: Fischer et al:: Mechanisms for synchronized burst

firing in pyramidal cells using oscillatory inhibition: a model for attentional control. BMC Neuroscience 2015 16(Suppl 1):P259.

\section{Submit your next manuscript to BioMed Central} and take full advantage of:

- Convenient online submission

- Thorough peer review

- No space constraints or color figure charges

- Immediate publication on acceptance

- Inclusion in PubMed, CAS, Scopus and Google Scholar

- Research which is freely available for redistribution

Submit your manuscript at www.biomedcentral.com/submit
(Ciomed Central 